\title{
Roles of the oviduct in mammalian fertilization
}

\author{
P Coy ${ }^{1}$, F A García-Vázquez ${ }^{1}$, P E Visconti ${ }^{3}$ and M Avilés ${ }^{2}$ \\ Departments of ${ }^{1}$ Physiology, Faculty of Veterinary and ${ }^{2}$ Cell Biology and Histology, Faculty of Medicine, University of \\ Murcia, Campus Mare Nostrum, Campus de Espinardo, Murcia 30071, Spain and ${ }^{3}$ Department of Veterinary and \\ Animal Sciences, University of Massachusetts, Amherst, Massachusetts, USA
}

Correspondence should be addressed to P Coy; Email: pcoy@um.es

\begin{abstract}
The oviduct or Fallopian tube is the anatomical region where every new life begins in mammalian species. After a long journey, the spermatozoa meet the oocyte in the specific site of the oviduct named ampulla and fertilization takes place. The successful fertilization depends on several biological processes that occur in the oviduct some hours before this rendezvous and affect both gametes. Estrogen and progesterone, released from the ovary, orchestrate a series of changes by genomic and nongenomic pathways in the oviductal epithelium affecting gene expression, proteome, and secretion of its cells into the fluid bathing the oviductal lumen. In addition, new regulatory molecules are being discovered playing important roles in oviductal physiology and fertilization. The present review tries to describe these processes, building a comprehensive map of the physiology of the oviduct, to better understand the importance of this organ in reproduction. With this purpose, gamete transport, sperm and oocyte changes in the oviductal environment, and other interactions between gametes and oviduct are discussed in light of recent publications in the field.

Reproduction (2012) 144 649-660
\end{abstract}

\section{The spermatozoon in the oviduct}

\section{Arrival, binding to, and releasing from epithelial cells}

Depending on the species, the sperm are deposited in different sections of the female tract. In a large number of mammals, the semen is ejaculated into the anterior vagina during coitus (e.g. cows, sheep, rabbits, primates, dogs, and cats). In others, sperm are placed in the cervix (e.g. sows) or directly spurted into the uterus (horses and many rodents). Regardless of where the sperm is initially dropped, to encounter the oocyte, the sperm is required to go through the uterotubal junction and enter the oviduct.

However, not all the ejaculated spermatozoa reach this initial portion of the oviduct. Once ejaculated, most sperm are eliminated from the female tract by different mechanisms (Yanagimachi 1994). A very low percentage of the sperm population is able to reach the ampulla or the ampullar-isthmic junction, and a recent work using genetically modified mice models has shown that a critical step in sperm transport is their migration through the uterotubal junction (Tokuhiro et al. 2012). Although the molecular basis of this transport is not well understood, it has been observed that knockout models with deficiencies in this transport are infertile. Presently, analysis of sperm from eight different knockout mice has shown problems in uterotubal junction transport. The null mice models presenting this phenotype include those for Ace (Hagaman et al. 1998), Adam1a (Nishimura et al. 2004), Adam2 (Cho et al. 1998), Adam3 (Shamsadin et al. 1999), Calr3 (Ikawa et al. 2011), Clgn (Ikawa et al. 1997), Tpst2 (Marcello et al. 2011), and Pdilt (Tokuhiro et al. 2012). It is interesting that all these models appear to converge in the lack of ADAM3; therefore, it has been hypothesized that this molecule is central to uterotubal transport and the other knockout models presenting this phenotype are involved in the process and regulation of ADAM3.

Once in the isthmus, the spermatozoa are bound to the ciliated epithelial cells. This process seems to be mediated by carbohydrate residues present in the oviductal epithelial cells and lectin-like proteins on the sperm head (Suarez 2002). The molecules involved in this process vary among species (Talevi \& Gualtieri 2010). In hamsters, sperm binding to oviductal epithelium is mediated by sialic acid (DeMott et al. 1995) and by galactose in horses (Dobrinski et al. 1996). In pigs, galactosyl and mannosyl residues seem to be involved in sperm-oviduct binding (Ekhlasi-Hundrieser et al. 2005). In cattle, strong evidence supports the involvement of fucose residues that are recognized by spermadhesin BSP1 (also called PDC-109) (Ignotz et al. 2001, Gwathmey et al. 2003, Sostaric et al. 2008), and in llamas (camelid), $\mathrm{N}$-acetylgalactosamine and galactose have been observed that inhibit the sperm binding to the oviductal cells (Apichela et al. 2010). 
From the sperm side, several proteins have been shown to have carbohydrate-binding affinities and could then interact with the epithelial cells. Thus, it was previously reported that the spermadhesins AQN1 and $A W N$ bind to the sequences Gal $\beta 1,3 \mathrm{GalNAc}$ and Galß1,4GlcNAc (Dostàlovà et al. 1995, Calvete et al. 1996). AQN1 also bind to mannose residues (Ekhlasi-Hundrieser et al. 2005) and, in the bovine species, spermadhesin BSP1 is able to recognize fucose residues (Gwathmey et al. 2003).

Independent of the specific carbohydrate residues or the lectin-like proteins participating in the adhesion, the role of the oviduct in such sperm-epithelial cell interaction seems to be the formation of a sperm reservoir. The more plausible explanation for the formation of a sperm reservoir in different species of mammals is the sequential releasing of sperm to allow only a small quantity of them reaching the oocyte at any given time and therefore reducing the possibility of polyspermy (Hunter \& Léglise 1971, Hunter 1973). Interestingly enough, the sperm release is modulated by the female estrous cycle with increased activity observed during the periovulatory period (Suarez 2008b) and it is probably related to the existence of unknown signaling between the recently attached cumulus-oocyte complex (COC) and the oviductal cells (Kölle et al. 2009) and with the progesterone $\left(\mathrm{P}_{4}\right)$ levels (Bureau et al. 2002).

Although the mechanisms responsible for sperm release are not well understood, it seems that the number of carbohydrate binding sites present in the oviductal epithelium surface is not greatly affected (Suarez et al. 1991, Lefebvre et al. 1995, Baillie et al. 1997). However, it has been proposed that this release is correlated with capacitation events (Smith \& Yanagimachi 1991, Lefebvre \& Suarez 1996). On the one hand, sperm release could be due to a loss of proteins involved in binding the sperm to the oviduct. As an alternative possibility, as part of the capacitation process, hyperactivation of the sperm motility might play an important role allowing these cells to escape the attachment by shear force (Demott \& Suarez 1992, Pacey et al. 1995). Even though, it cannot be discarded that both mechanisms are coordinated to free the sperm from the epithelium, but additional hypothesis is also emerging.

Due to the complex protein composition found in the oviductal fluid (Avilés et al. 2010, Mondéjar et al. 2012a), two additional mechanisms could contribute to the regulation of the sperm oviductal interaction. First, activities for different glycosidases have been detected in the oviductal fluid showing variations along the estrous cycle (Carrasco et al. 2008a, 2008b). These enzymes could act on the specific carbohydrate residues present in the epithelial cells necessary for the sperm binding and contribute to the release of the sperm from the reservoir. Supporting this model, it is important to point out that the best characterized sperm-oviductal interaction was described in the bovine model (Fig. 1). In this species, it was reported that sperm protein BSP1 recognizes specifically the fucose residues contained in the annexin present at the oviductal epithelium (Hung \& Suarez 2010). Thus, fucosidase activity, present in the oviductal fluid (Carrasco et al. 2008b), could contribute to the regulation of the binding. Additionally, the presence of annexin in the oviductal fluid (Mondéjar et al. 2012a) could also participate in such regulation, as the atypical secretion of this protein has been reported previously (Christmas et al. 1991).

Secondly, as mentioned earlier, AWN has the ability to bind to carbohydrate residues. Unexpectedly, it was reported that this protein is secreted by the epithelial cells in the swine oviduct (Song et al. 2010) and, consequently, could compete with the sperm for oviductal carbohydrates suggesting its participation in the sperm-releasing process. Additional experiments are necessary to confirm these different hypotheses. The development of improved experimental conditions as the use of labeled sperm, video microscopy, and the in vitro system culture for oviductal epithelium will bring more light about the molecular mechanisms involved in the sperm-oviduct interaction (Miessen et al. 2011).

\section{Capacitation}

As explained earlier, it has been hypothesized that release of the sperm from the oviductal epithelium is due to their capacitated state (Smith \& Yanagimachi 1991, Lefebvre \& Suarez 1996). Discovered independently by Austin (1951) and Chang (1951), capacitation has been defined as those physiological events that render the sperm able to fertilize. Discovery of capacitation was fundamental to allow development of IVF. First demonstrated in rabbits in 1959 (Chang 1959), this technology led to the first test-tube baby in 1978 when Mary Louise Brown was born (Steptoe \& Edwards 1978). This success was recognized in 2010 when Dr Roberts was awarded the Nobel Prize in Medicine. Although the initial experiments by Chang and Austin were conducted using artificial insemination in live female rabbits, most of what it is known about this process is derived from in vitro experimentation. In vitro capacitation in most mammalian species is achieved by incubation of the sperm in a simple media that mimic the oviductal milieu. In particular, capacitation-supporting media requires bicarbonate, calcium, energy sources, and serum albumin as a cholesterol-binding compound.

One critical change in the sperm-surrounding milieu after ejaculation is the change in $\mathrm{HCO}_{3}^{-}$concentration (Fig. 2). This anion plays a role in the regulation of the cAMP pathway (Visconti et al. 2011) through the stimulation of a unique type of adenylyl cyclase present in sperm, known as soluble adenylyl cyclase 


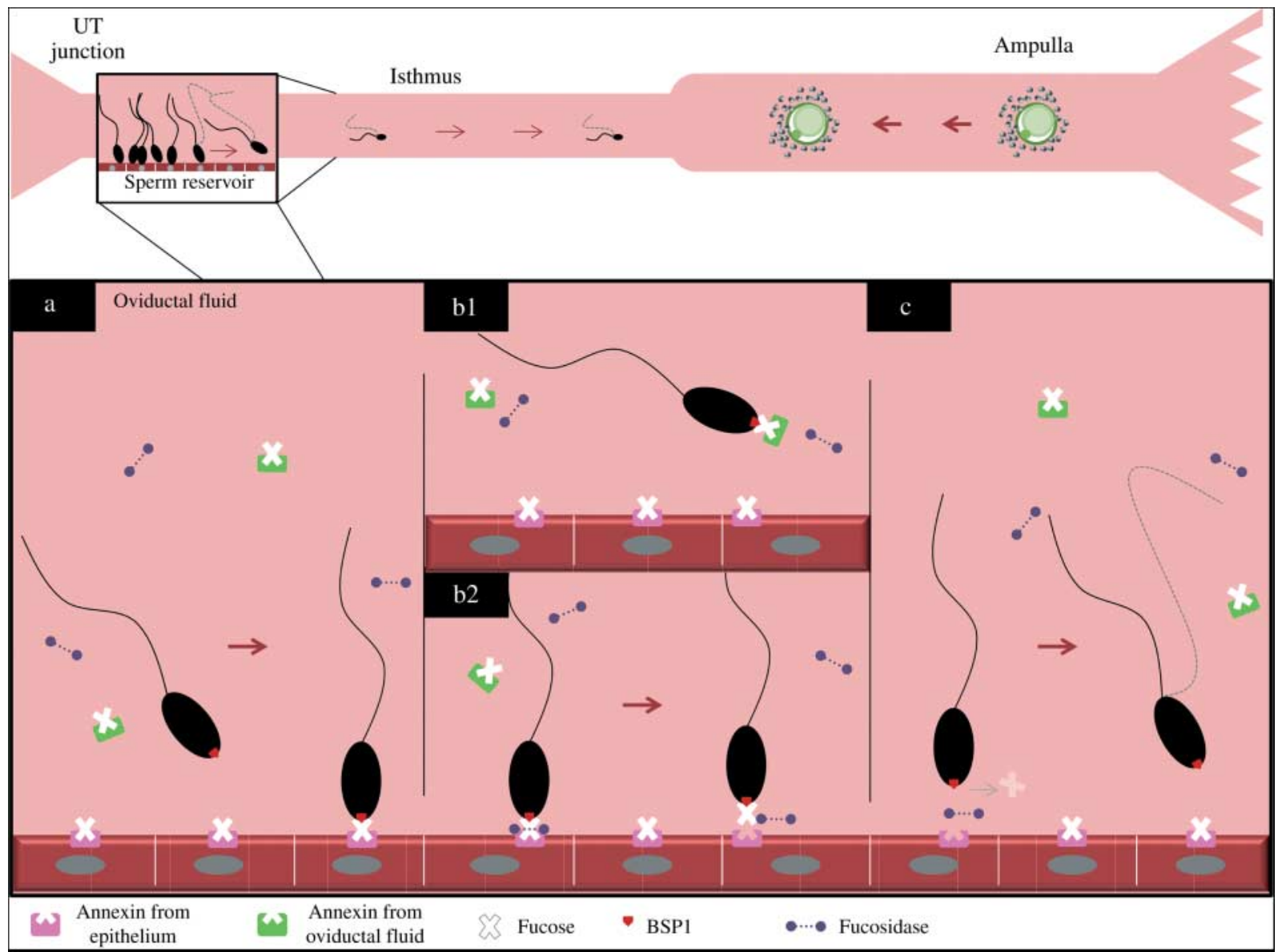

Figure 1 Mechanism for the sperm binding and releasing from the oviduct in the bovine model. (a) Sperm binding is mediated by lectin-like protein as BSP1 present in the sperm plasma membrane that recognizes fucose contained in the annexin molecule bound to the epithelial cell membrane. (b) Sperm binding to the oviduct could be modulated by two different mechanisms that can act at the same time. (b1) Annexin present in the oviductal fluid compete for the BSP1 binding site present on the sperm. (b2) Fucosidase enzymes present in the oviductal fluid can remove fucose residues contained in the annexin present in the oviductal epithelium. (c) These different mechanisms and the development of hyperactivative motility allow the sperm release from the oviductal reservoir.

(SACY; Buck \& Levin 2011). SACY knockout mice are sterile (Hess et al. 2005, Xie et al. 2006) and their sterility phenotype is mapped to a lack of capacitation; in particular, sperm from the SACY null mice are not able to move actively and cannot hyperactivate (Hess et al. 2005). Consistent with the role of cAMP in capacitation, a similar phenotype is observed when the testis-specific protein kinase A (PKA) catalytic subunit splicing variant is eliminated by homologous recombination. Using sperm of these mice in vitro, the authors clearly showed that PKA is required for the activation of flagellar beat and for the flagellar waveform asymmetry associated with hyperactivation (Nolan et al. 2004). In addition to genetic approaches, the role of CAMP in the regulation of sperm is also supported by biochemical and pharmacological approaches. Inhibitors of PKA such as H89 and rpScAMP and peptides that disrupt PKA binding to anchoring proteins block sperm motility and IVF (Visconti et al. 1995, Vijayaraghavan et al. 1997). Downstream of the activation of a cAMP/PKA pathway, capacitation in vitro is also associated with an increase in protein tyrosine phosphorylation (for review, see Visconti et al. (2011)). Despite the fact that many groups have shown similar regulatory pathways in sperm from other species, there is still a limited knowledge on the identity and the role of proteins phosphorylated during capacitation.

Although it is believed that the regulation of signaling pathways in vitro mimic those happening in vivo, this possibility has not yet been demonstrated. Activation of PKA occurs immediately upon ejaculation, once the $\mathrm{HCO}_{3}^{-}$concentration surrounding the sperm milieu increases from low millimolar levels in the cauda epididymis to $\sim 25 \mathrm{mM}$ concentration in the semen and female tract fluids. However, tyrosine phosphorylation and hyperactivation are not believed to occur until the sperm reach the oviduct.

As mentioned earlier, most of what it is known about the signaling events controlling sperm capacitation was obtained from in vitro experiments. While these 


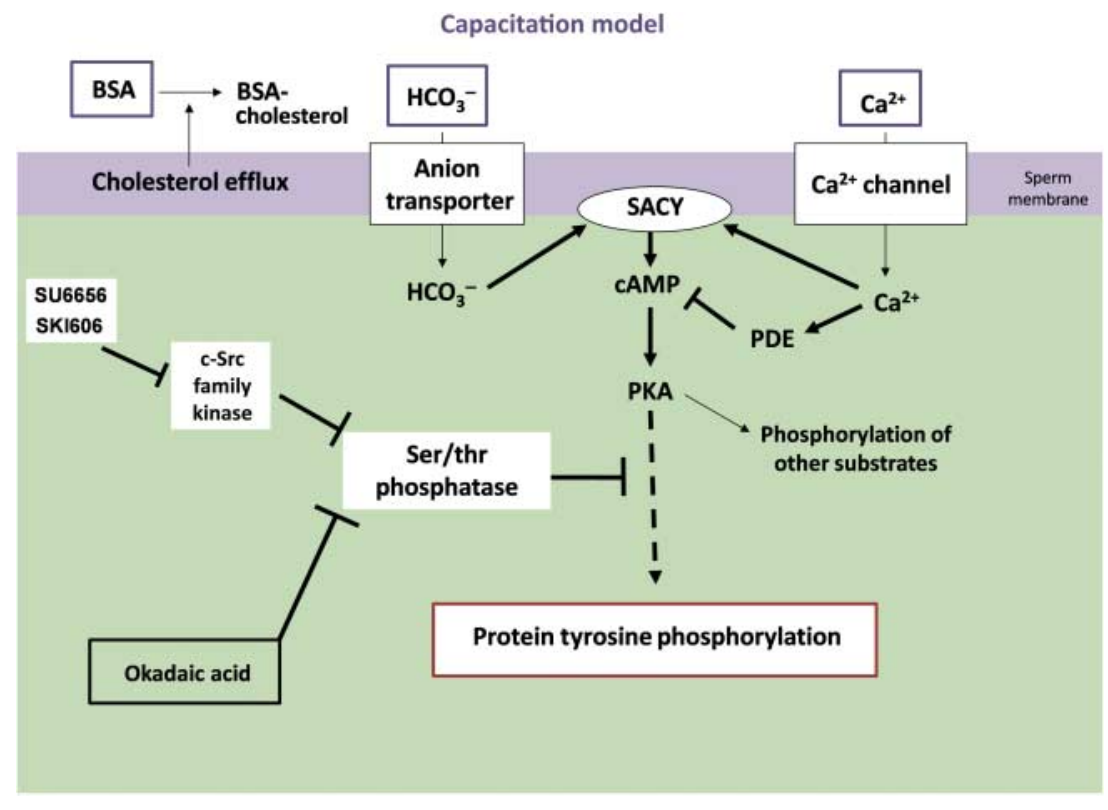

Figure 2 Model for the regulation of sperm capacitation. Removal of cholesterol by BSA modulates the influx of $\mathrm{HCO}_{3}{ }^{-}$and $\mathrm{Ca}^{2+}$. These ions regulate the activity of the sperm-soluble adenyl cyclase (SACY), increasing intracellular cAMP, and activating PKA. The activation of CSrC family kinase sensitive to both SU6656 and SKI606 downregulates a ser/thr phosphatase, which modifies the phosphorylated steady state of PKA substrates. As a consequence, the onset of PKA phosphorylation is followed by the promotion of tyrosine phosphorylation associated with sperm capacitation. Okadaic acid is a known ser/thr phosphatase inhibitor and can induce some of the capacitation-associated processes.

observations are important, they do not address how the female tract controls the speed of capacitation and delivers freshly capacitated sperm to the ovulated eggs. The assumption that capacitation is regulated by the same signaling pathways in vivo as in vitro, although logical, has not yet been tested. Studies of in vivo capacitation are more complex because of the more difficult access to the sperm and also because of the smaller quantity of cells that can be obtained. Because of these limitations, novel approaches should be developed. Among them, the analysis of phosphorylation pathways could be performed by immunofluorescence analysis using anti-phospho antibodies such as anti-phospho PKA substrate or anti-phosphotyrosine antibodies (Krapf et al. 2010). Some of the challenges presented by these experiments are i) that these experiments should be conducted in static fixed sections which would not allow following the fate of the signaling changes in live sperm and ii) that sections could cut the sperm in planes not compatible with anti-phospho staining making it difficult to quantify the level of phosphorylation. Despite these perceived problems, this approach has the advantage that it does not need a lot of material as in the case of western blots used in most in vitro experiments. In addition, sections of oviducts have been used successfully to visualize fluorescent mouse sperm in the oviduct (Tokuhiro et al. 2012), and confocal microscopy or even multiphoton microscopy can be used to optically assess thick sections of oviduct to provide more complete and clear images of different sperm compartments. Alternatively, it is predicted that the use of genetically modified mice in which fluorescent markers of capacitation are inserted through transgenic technology would allow investigating how the sperm behaves in vivo. This technology has been used to observe the acrosome reaction (AR) using sperm in which the green fluorescent protein is targeted to the acrosomal compartment (Nakanishi et al. 1999).

\section{Sperm hyperactivation}

The oviduct takes care of and modifies the sperm in such a way that it is able to fertilize. One of these modifications is the sperm pattern motility.

Sperm within the epididymis are unmotile or poorly motile (inactivated). When they are released from the epididymis and mixed with the seminal plasma, they become activated. The term 'activated motility', described by Yanagimachi (1994), means that the sperm start to swim straight and vigorously with symmetrical flagellar beats. Once the activated sperm are in the female tract after mating, only a small population (hundreds to thousands) will be able to reach the oviduct and become established in the sperm reservoir (described earlier). Spermatozoa in this storage place are attached and stabilized during the preovulatory interval with suppressed motility and intact surface membranes (for review, see Hunter (2012)), but later sperm will detach acquiring another motility pattern named 'hyperactivated motility' (Fig. 3a). This condition was defined for the first time by Yanagimachi (1970) who observed that hamster sperm in the oviduct had a very vigorous motility pattern with high amplitude and asymmetrical flagellar beating. In the years following that discovery, it was demonstrated that the 'hyperactive motility' is essential for the sperm to fertilize. So, this term was redefined as the swimming pattern shown by most sperm retrieved from the oviductal ampulla at the time of fertilization (Suarez \& Ho 2003).

But, when do mammalian spermatozoa become hyperactivated? One of the known triggers is the increase 


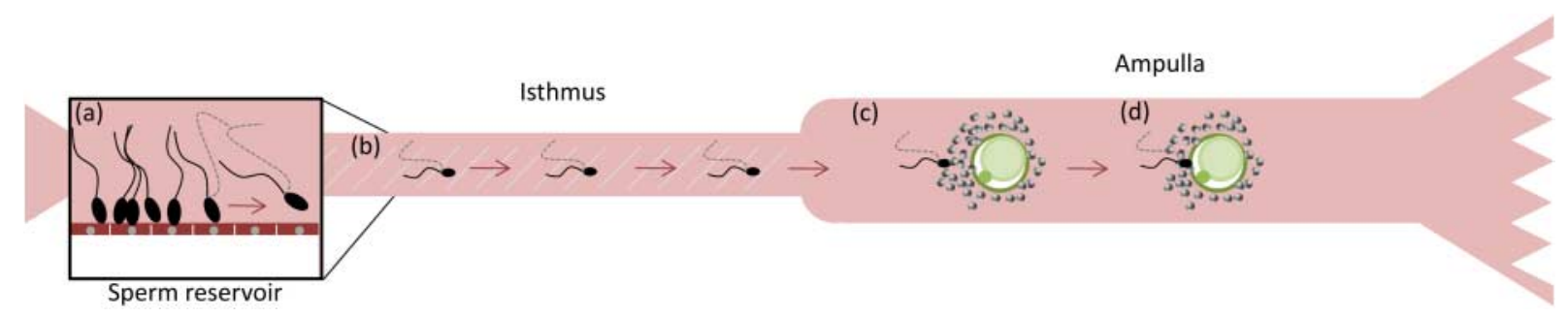

Figure 3 Roles of the hyperactivation induced by the oviduct on the sperm during the approach to the oocyte: (a) detaching of the sperm from the epithelial cells, (b) transport to the fertilization site, (c) cross through cumulus cells, and (d) penetration of zona pellucida.

in intracellular $\mathrm{Ca}^{2+}\left(\left[\mathrm{Ca}^{2+}\right]_{\mathrm{i}}\right)$ (Publicover et al. 2008). This is probably prompted by ovulation and is a consequence of $\mathrm{P}_{4}$ secretion influencing the oviduct epithelium (for review, see Hunter (2012)) and helping sperm transport to the fertilization place (Chang \& Suarez 2012). And, how is $\mathrm{Ca}^{2+}$ mobilized into the cytoplasm to induce hyperactivation? Spermatozoa require $\mathrm{Ca}^{2+}$ channels in the plasma membrane, which have been identified and named as CATSPER1 (CATSPER) proteins (CATSPER1-4), located in the principal piece of the flagellum (Kirichok et al. 2006, Qi et al. 2007). In fact, several reports have shown that male mice null mutant for Catsper1 genes are infertile (Ren et al. 2001, Quill et al. 2003, Jin et al. 2007, Qi et al. 2007), suggesting that the reason is the lack of hyperactivation in the spermatozoa of these animals (Ren et al. 2001, Quill et al. 2003). Ho et al. (2009) supported this hypothesis because spermatozoa from Catsper-null mutants did not detach from the epithelium or show deep asymmetrical flagellar bending. As indicated earlier, $\mathrm{P}_{4}$ could be involved in sperm detachment (Bureau et al. 2002) and hyperactivation. It is known that $\mathrm{P}_{4}$ rises $\left[\mathrm{Ca}^{2+}\right]_{i}$ levels in human sperm (Publicover et al. 2007) but it is not known by which mechanism. Recently, Lishko et al. (2011) and Strünker et al. (2011) explained the action of this hormone on human spermatozoa where the $\mathrm{P}_{4}$, in combination with an elevation of intracellular $\mathrm{pH}$, activates the CatSper channels involved in $\mathrm{Ca}^{2+}$ human sperm intake. The extracellular $\mathrm{pH}$ increase in oviductal fluid during estrus could possibly be the primary factor for inducing hyperactivation in the oviduct, activating CatSper and raising intracellular $\mathrm{pH}$ (Suarez 2008a). $\mathrm{HCO}_{3}^{-}$levels could play an important role for this purpose.

Summarizing the oviductal influence on spermatozoa physiology, an increasing body of research suggests that periovulatory changes in $\mathrm{pH}$, temperature, $\left[\mathrm{Ca}^{2+}\right]$, and $\mathrm{HCO}_{3}^{-}$levels in the oviductal fluid modulate different aspects of sperm function, including releasing from the epithelial cells, membrane modifications leading to capacitation, and the hyperactive motility that addresses them to the oocyte vicinity (Hunter \& Nichol 1986, Rodriguez-Martinez et al. 2001, Rodriguez-Martinez 2007, Coy et al. 2010, Zumoffen et al. 2010, Kumaresan et al. 2012).

\section{The oocyte in the oviduct}

\section{Arrival to the fertilization site}

The role of the oviduct on the oocyte transport has been classically attributed to the cilia beating and smooth muscle activity, speeded up by estrogens and slowed down by $\mathrm{P}_{4}$, when administrated in adequate dosages and times (Chang 1966). This principle is still valid, and modern video microscopy and biochemical techniques have contributed to describe the process in detail.

From studies in hamsters, the importance of the cumulus cells and the extracellular matrix of the COC on the picking up and initial adhesion to the infundibulum cilia was shown. Slight changes in the level of COCs expansion affected the initial adhesion and made their further transportation difficult (Talbot et al. 2003). Cilia that cover the exterior surface of the infundibulum beat in the direction of the ostium induce a current of oviductal fluid and move the COC into the oviduct. It was suggested in mice and humans that the $\mathrm{P}_{4}$ receptor, localized in the lower half of the motile cilia of oviduct ciliated epithelial cells, may directly regulate ciliary beat frequency (Teilmann et al. 2006), thus confirming the initial discoveries by Chang (1966).

Although it is a key factor, ciliary beating alone cannot provide the propulsive force behind oocyte movement along the oviduct. Spontaneous contractions of the oviduct are also necessary, and interstitial cells of Cajal associated with the smooth muscle cells along the entire length of the oviduct are responsible for electrical slow-wave events that couple in a one-to-one relationship with phasic contractions of the myosalpinx (Dixon et al. 2009). Dixon et al. demonstrated that these slow waves are not initiated by neural inputs, but they are driven by pacemaker activity provided by the oviductal cells of Cajal.

Another interesting body of research about oviductal motility and oocyte transport is that concerning the role of nitric oxide synthases (NOS). Lapointe et al. (2006) showed in the bovine oviduct that expression of inducible NOS is selectively upregulated by estradiol during the temporal window of oocyte transport. As NO plays a role as a relaxing agent in mammalian oviduct and its inhibition accelerates oocyte transport (Perez Martinez et al. 2000), regulation of NOS by estradiol suggests a fine-tuned equilibrium of 
the oviductal motility. Such equilibrium seems to be reached by nongenomic pathways of estradiol action including estradiol bound to its receptors, activation of CAMP, and partial participation of PKA (Orihuela et al. 2003) that again confirm Chang's discoveries.

\section{Oocyte's changes in the oviduct}

Once in the ampulla, transported by the cilia beating and smooth muscle contractions, the COC remains attached to the epithelium for a variable period of time. While previous in vivo studies in the pig model indicated that unfertilized oocytes reached the ampullar-isthmic region within 30-45 min from the beginning of ovulation (Hunter 1974) and that spermatozoa met them in this site, digital video microscopical studies in the cow oviduct have suggested that as soon as the mature COCs enter the ampulla, they are immediately firmly attached to the oviductal epithelium (Kölle et al. 2009). Whether inter-specific differences between the pig and cow or methodological differences between the experiments (in vivo in the pig and ex vivo in the cow) explain this controversy remains elusive.

One important change for the oocyte at this time is related to the removal of its investments: in some species, such as cows and sheep, cumulus cells are rarely detected around recently ovulated oocytes, whereas in primates and in pigs cumulus cells and oocytes are immersed in a dense plug (Hunter 1989). Even in this case, the plug is dissolved in the porcine species a few hours later and oocytes collected from the oviduct become naked within $1 \mathrm{~h}$ (Coy et al. 1993). However, a general consensus exists, based on wide experimental evidence, about the improving of the fertilization rates in most mammalian species in the presence of cumulus cells (Campos et al. 2001, Zhuo et al. 2001, Van Soom et al. 2002), underlying the importance of a rapid response of the oviduct, releasing the sperm from the reservoir, as soon as the oocyte arrives surrounded by the cumulus.

During the process of cumulus expansion and disaggregation, zona pellucida (ZP) becomes more accessible to the oviductal fluid permitting its modification by different molecules. Differences in ZP among oviductal and follicular oocytes, or zona maturation, have been referred by a number of authors, most of them related to changes at the ultrastructural level (Funahashi et al. 2001) and a few of them identifying specific molecules in the oviductal ZP that are not present in the ovarian ZP. Among them, oviductspecific glycoprotein (OVGP1), osteopontin, and lipocalin-type prostaglandin D synthase were demonstrated to associate with the bovine ZP (Goncalves et al. 2008). Moreover, OVGP1 and heparin-like glycosaminoglycans (GAGs) from the oviductal fluid have been demonstrated in the pig and cow to participate in the functional modification of the ZP that, before fertilization, makes it more resistant to enzymatic digestion and to sperm penetration, contributing to the control of polyspermy (Coy et al. 2008). This mechanism is represented in Fig. 4. Finally, there is also a significant change in the sugar moieties of glycoproteins in the ZP following ovulation (Avilés et al. 1996, Aviles et al. 1997, El-Mestrah \& Kan 2001), although the specific role of these changes needs to be investigated. Studies completing the list of proteins and sugars binding to the $\mathrm{ZP}$ in the oviduct could contribute to the comprehension of the molecular events affecting the sperm-oocyte interaction and to the definitive description of a model assigning to each molecule its specific role in this complex mechanism.

\section{Oocyte-sperm-oviduct interactions}

\section{Oviductal influence on the initial sperm approach to the oocyte}

Once the sperm are hyperactivated and released into the oviduct, how do the sperm know which direction to travel in order to reach the oocyte? The sperm in the reservoir (Fig. 3a) are like the boats docking in a port'... they are attached, but when they are released ('sailing on the sea') they need a guide ('navigator') to reach the objective that in the sperm's case is the fertilization place. Thermo- and chemotaxis have been defined, in terms of fertilization, as the process by which

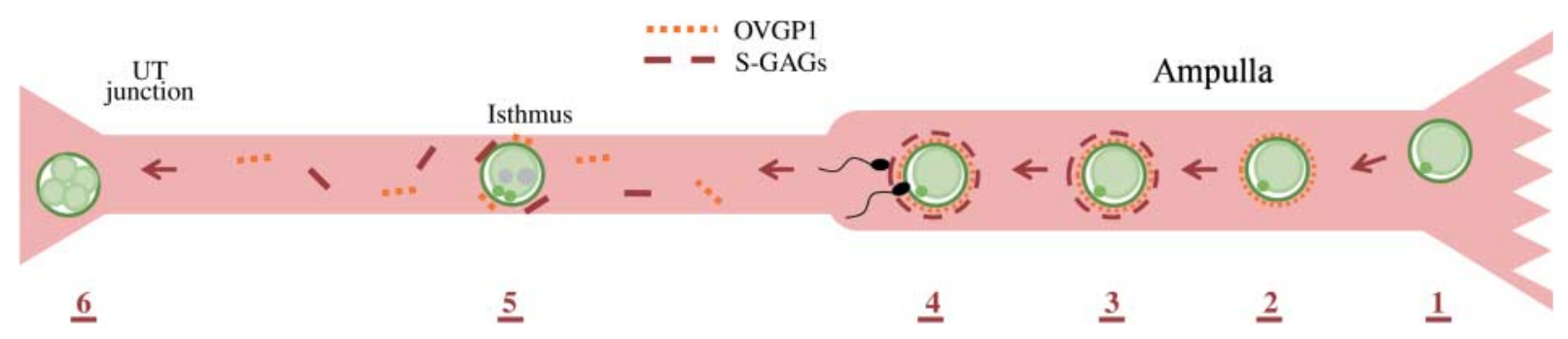

Figure 4 Pre-fertilization ZP hardening (adapted from Coy \& Avilés (2010)). 1) When the oocyte is shedding in the ampulla soon after ovulation, oviduct-specific glycoprotein (OVGP1) surround it in a 'shell' 2) that is responsible for the ZP resistance to proteolysis. 3) Heparin-like GAGs in the oviduct fluid stabilizes and reinforces the binding of OVGP1 with ZP, which determines the interaction of selected spermatozoa 4) with such a modified ZP. 5) In the transit toward the uterus, the system is destabilized and OVGP1 is partially unbound or internalized. 6) Thus, ZP in the embryo reaching the uterus returns to the low resistance to proteolysis showed by the ovarian oocyte in (1). 
sperm are guided by a temperature gradient (cooler to warmer; for review, see Eisenbach \& Giojalas (2006)) or by a chemical gradient (Chang \& Suarez 2010) to reach the oocyte. There are only a few studies about the motility on mammalian sperm responses to these gradients. Some substances have been identified as potential chemoattractants; for example, the $\mathrm{P}_{4}$ that is released during the ovulation (present in follicular fluid) and is produced by the cumulus cells that surround the oocytes (Chang \& Suarez 2010). It has been postulated that $\left[\mathrm{Ca}^{2+}\right]_{i}$ increases during sperm chemotaxis (i.e. $\mathrm{P}_{4}$ ) induce turning swimming with asymmetric flagellar bending (for review, see Yoshida \& Yoshida (2011)). Other components in oviductal fluid have been identified as chemoattractant, that is, the case for natriuretic peptide precursor, that modifies the sperm pattern motility and enhances $\left[\mathrm{Ca}^{2+}\right]_{i}$ levels, whose receptor has been recently shown in mouse spermatozoa (Bian et al. 2012). Temperature also seems to play a role in the levels of $\left[\mathrm{Ca}^{2+}\right]_{\mathrm{i}}$. Temperature stimulation activates the release of the internal sperm $\mathrm{Ca}^{2+}$ store affecting flagellar bending (Bahat \& Eisenbach 2010). In addition to chemo- and thermotaxis, other factors as the movement of oviductal fluid, oviductal contractions, oviductal epithelium, and the internal structure of the oviduct (Burkitt et al. 2012) could also influence the sperm transport and guidance, although the evidence of these aspects has not yet been demonstrated in vivo.

After the sperm are hyperactivated and guided to the oocyte, they have to propel themselves through the viscous glycoprotein secretion in the oviduct toward the ampullar-isthmic junction (Fig. 3b). During the preovulatory stage, the mucus within the oviduct is extremely viscous before ovulation and may contribute to the suppression of sperm motility (Hunter et al. 2011); after ovulation, it become less viscous which would facilitate an adequate flagellar beat and progression of spermatozoa toward the ampulla (Suarez \& Dai 1992, Hunter et al. 2011). Suarez \& Dai (1992) showed an increase in flagellum propulsion when mouse sperm was confronted with an increase viscosity gradient medium. So, it seems that spermatozoa escape from the viscous fluid thanks to the hyperactivation. The flagellar beating during hyperactivation has been widely reported in vitro, but only a few experiments show the flagellar behavior simulating real conditions. Recently, Chang \& Suarez (2012) have recorded mice sperm in the oviduct in conditions very close to in vivo. These authors showed a different motility pattern called anti-hook instead of pro-hook beating (amplitude of the bend in the same orientation as the hook of the head) described before in in vitro situations. The cause of these differences could be found (among other factors) in the composition (mucoid type) and viscosity of the oviductal fluid that are absent in most of the in vitro media used, making the sperm to propel themselves (better than to swim) in such a semisolid environment.
What seems to be obvious it is that sperm are exposed to a different microenvironment (viscosity, chemical agents, temperature, etc.) in their travel through the oviduct and they are continuously re-adapting their pattern motility to these conditions. As suggested by Brenker et al. (2012), CatSper could function as a polymodal translator for the chemical and physical code of each microenvironment into $\mathrm{Ca}^{2+}$ patterns to reach the site of fertilization.

Once the sperm reach the oocytes, they have to cross the cumulus cells surrounding them (Fig. 3c). Sperm GPI-anchored surface hyaluronidases and hyperactivated sperm motility are thought to be sufficient for the sperm to get through the cumulus (for review, see Yin et al. (2009)). Carrasco et al. (2008a, 2008b) have described some hexosaminidases in oviductal fluid (as it has been indicated in 'Arrival, binding to, and releasing from epithelial cells' section), which could be responsible for cumulus cell disaggregation from ovulated oocytes helping the sperm to cross this barrier. In addition, it was previously reported that SPAM1 (with hyaluronidase activity) is secreted by the oviduct and consequently can participate in the cumulus oophorus dispersion (Griffiths et al. 2008). Preliminary data from our laboratory also described the presence of the SPAM1 in the porcine and bovine oviduct (Acuña et al. 2011).

Moreover, in the latest reports, AR has also been observed during the sperm pass through the cumulus (Yin et al. 2009, Jin et al. 2011). Indeed, as Yanagimachi (2011) pointed out recently, the place where AR begins in mammalian sperm before fertilization has been a controversial topic. On one side of the debate, some researchers think that the AR takes place while the sperm advance through the cumulus, while on the other side, other scientists think that AR occurs on the surface of the $Z P$. On combining information from the latest reports, what seems to be clear is that the ZP may not be the only site of AR; therefore, cumulus cells play an important role in sperm AR. Among the potential chemoattractants, it is interesting to note that $\mathrm{P}_{4}$ secreted by cumulus cells is known to induce or promote the AR of spermatozoa of various species, but the spermatozoa in the oviduct are acrosome-intact or occasionally reacted (for review, see Sun et al. (2011)). The reason that the sperm in the oviduct are not reacted by $\mathrm{P}_{4}$ action is probably due to its concentration; the possibility is that sperm stimulation by low levels of $\mathrm{P}_{4}(\mu \mathrm{M}-\mathrm{mM})$ does not induce $A R$ (Publicover et al. 2008; Fig. 5). Gahlay et al. (2010) using transgenic mice (ZP2 ${ }^{\text {Mut }}$ and ZP3 ${ }^{\text {Mut }}$ ) suggested that sperm binding at the surface of the ZP is not sufficient to induce sperm AR. In fact, Jin et al. (2011) recorded that the spermatozoa beginning the AR before reaching the zona were able to penetrate it. A new protein called NYD-SP8 has been recently identified in the cumulussperm interaction triggering $\mathrm{Ca}^{2+}$ mobilization and $\mathrm{P}_{4}$ release from cumulus cells inducing the AR (Yin et al. 2009). It should be noted that no one has ever followed 


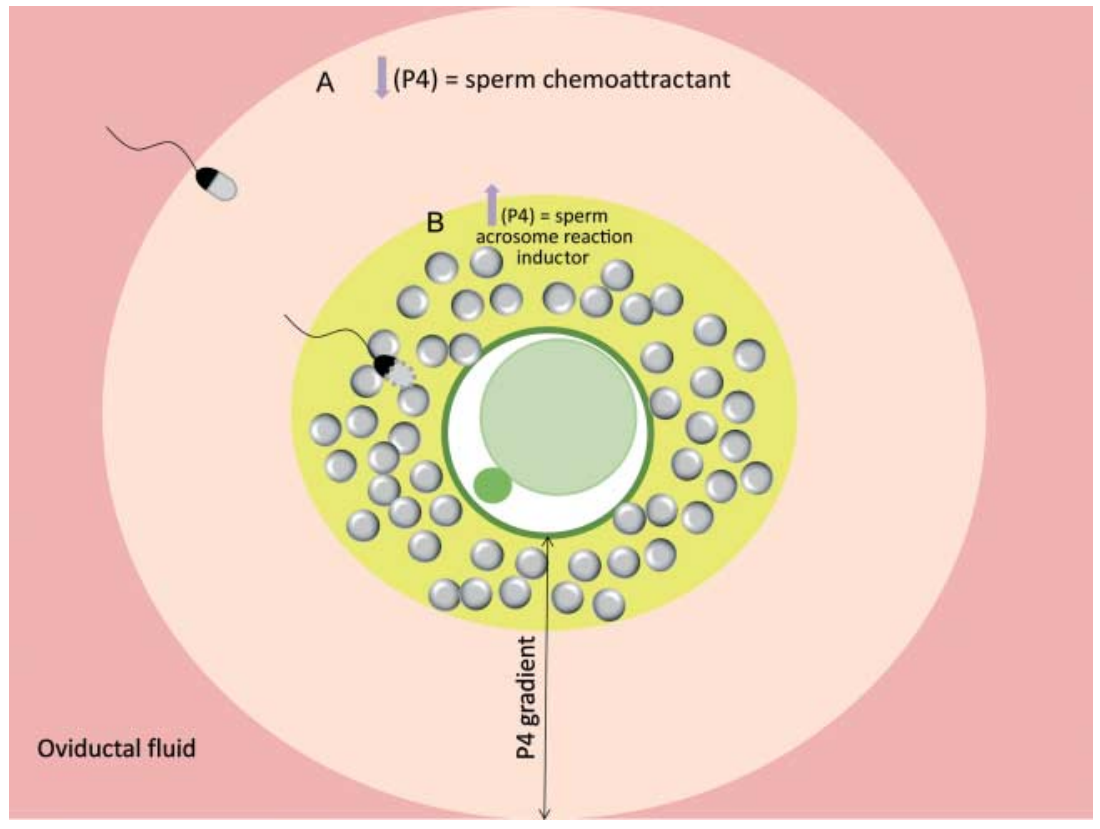

Figure 5 Progesterone $\left(\mathrm{P}_{4}\right)$ levels close to the fertilization location and its effect on sperm. (A) Low $\mathrm{P}_{4}$ levels acting like a chemoattractant driving the sperm toward the oocyte. (B) High $\mathrm{P}_{4}$ levels secreted by cumulus cells induce acrosome reaction. a single spermatozoon from the beginning of the AR until the end of fertilization, so the exact place where fertilizing spermatozoa begin their AR and what triggers the AR remain to be determined (Yanagimachi 2011).

All the described steps related to the sperm modifications since they are ejaculated are probably addressed to enable them to bind and penetrate the extracellular matrix of the oocyte, the ZP (Gadella 2010). This is the last barrier before gamete fusion (Fig. $3 \mathrm{~d}$ ). Although the true mechanism is still unclear, and it is not the objective of the present review to describe the different models proposed for the sperm-ZP binding in the different species, it has been hypothesized that the sperm penetration through the ZP is dependent either entirely or partly on the mechanical force that provided the hyperactivated sperm (Kim et al. 2008). In fact, when hyperactivation was blocked in hamster sperm bound to the $\mathrm{ZP}$, they were unable to penetrate it (Stauss et al. 1995) and, in this sense, hyperactivation induced by the oviduct can be considered as one more role of this organ in the fertilization process.

\section{Does the oviductal fluid has any effect on fertilization itself?}

Apart from its roles on the female and male gamete preparation for their meeting, discussed earlier, the question about the specific function of the oviduct or their secretions on the fertilization process itself, once the spermatozoon has bound to $\mathrm{ZP}$, has not received significant attention in the research literature. Until recently, no molecules present in the oviductal fluid, other than OVGP1, already mentioned as a molecule reducing the number of sperm bound to ZP (Coy et al. 2008), had been demonstrated to directly affect the fertilization but new information is coming out every day supporting this hypothesis.

First, quantification of activity for five glycosidases in the oviductal fluid, with changes along the estrous cycle, has brought about different proposals, such as the possible role of oviductal hexosaminidase in the sperm-ZP binding, hydrolyzing the $\beta$ - $N$-acetylglucosamine moieties at ZP (Carrasco et al. 2008b). Oviductal $\beta$-D-galactosidase could also regulate the sperm binding sites present in the ZP, as $\beta$-galactosyl residues in the $\mathrm{ZP}$ oligosaccharides have shown to be involved in porcine sperm-egg binding (Yonezawa et al. 2005). Further studies are necessary to describe the specific function of each glycosidase in the oviduct.

Secondly, plasminogen, a serum zymogen mainly produced by the liver, has also been quantified in the oviductal fluid and demonstrated to bind oocytes at ZP and oolemma level (Mondéjar et al. 2012b). Moreover, the different components of the plasminogen-plasmin system, including activators and inhibitors, are present in the oviduct and a model has been proposed by which, upon sperm contact to the oolemma, plasminogen activators are released from the oocyte (Fig. 6) and increase the conversion of the plasminogen into plasmin; such plasmin seems to remove spermatozoa attached to the $\mathrm{ZP}$, thus contributing to the regulation of sperm penetration in the oocyte (Coy et al. 2012).

Finally, attention must be paid to recent studies about changes in the oviductal secretory proteome and transcriptome induced by the arrival of oocytes or spermatozoa to this organ (Fazeli et al. 2004, 


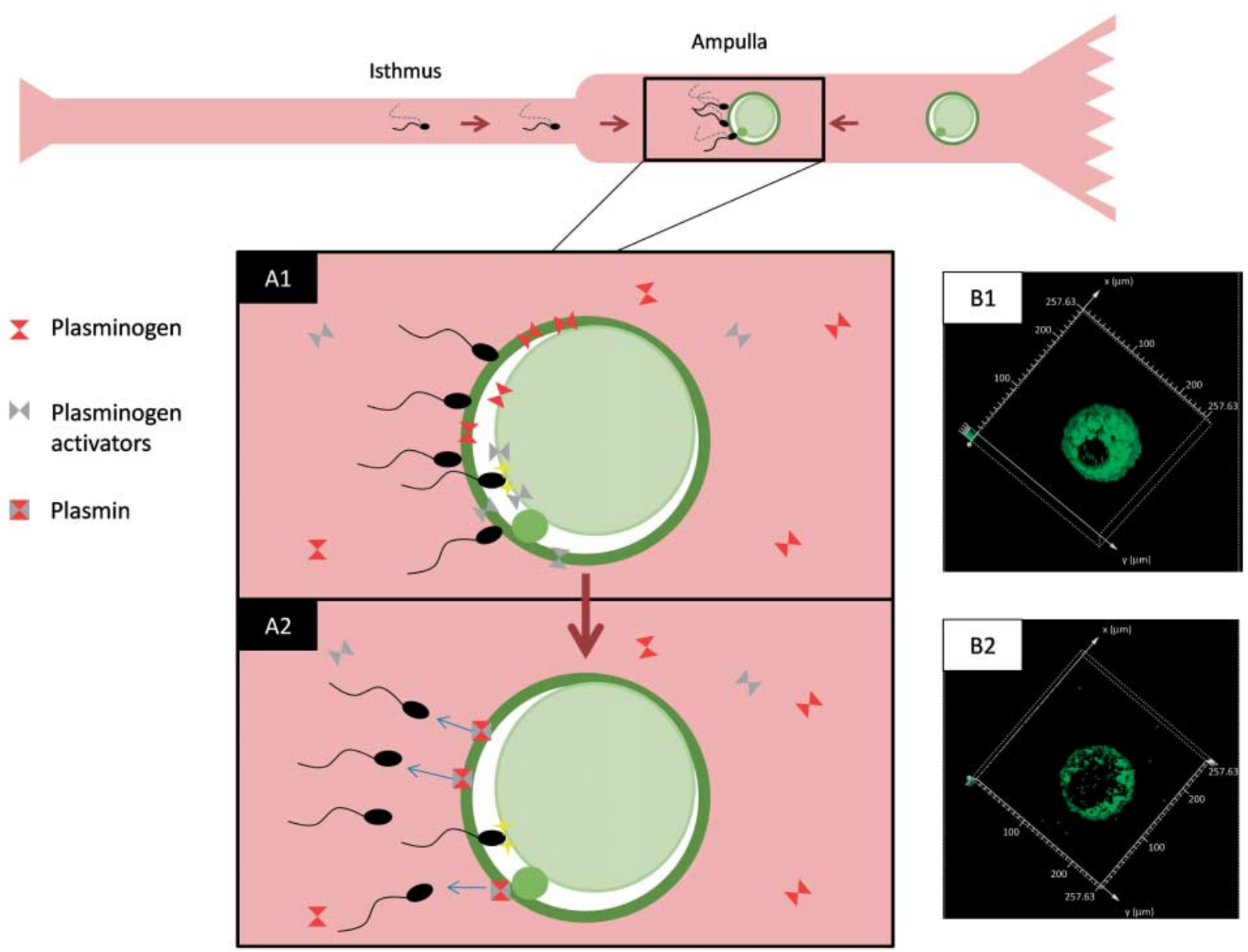

Figure 6 Proposed model for the role of the plasminogen-plasmin system during fertilization. Plasminogen and plasminogen activators are present in the oolemma and ZP of the oocyte (A1). Oocyte immunostaining with antibodies against plasminogen activators shows the oolemma strongly labeled (B1). When the spermatozoa bind the oolemma, plasminogen activators are released and increase the activation of the plasminogen into plasmin. Plasmin detaches additional spermatozoa bound to ZP (A2). The labeling in the oolemma decreases a few minutes after sperm binding (B2).

Georgiou et al. 2005). It seems clear that gametes modulate their own microenvironment and it can be anticipated that in the immediate future new molecules of oviductal origin participating in the fertilization process will be identified. Data from the whole oviductal transcriptome in different animal models and at the different phases of the estrous cycle would be very useful to complete the puzzle of the molecular pathways playing a role in the beginning of a new life (Mondéjar et al. 2012a).

\section{Concluding remarks}

A number of molecules participating in the oviductal signaling affects different steps in the fertilization process, including sperm binding and releasing from the oviductal epithelium, sperm capacitation and hyperactivation, oocyte oviductal maturation and prefertilization ZP hardening, sperm-ZP binding, and fertilization itself. Although descriptive genomic and proteomic studies have identified a high amount of candidate molecules participating in these processes (Fazeli et al. 2004, Georgiou et al. 2005), functional data are now necessary to understand the specific role of each molecule in each pathway. Only with these studies could be reached a significant advance in the comprehension of the fertilization process and, consequently, novel tools to modulate it, could be developed.

\section{Declaration of interest}

The authors declare that there is no conflict of interest that could be perceived as prejudicing the impartiality of the research reported.

\section{Funding}

This work was supported by grants AGL2009-12512-C02-0102 from the Spanish Ministry of Science and Innovation and FEDER (to P Coy, F A García-Vázquez, and M Avilés) and grants HD38082 and HD44044 from the National Institutes of Health (to P E Visconti). P Coy, F A García-Vázquez, and M Avilés are members of the COST Action GEMINI FA0702. 


\section{References}

Acuña OS, Stetson I, Izquierdo-Rico MJ, Coy P \& Avilés M 2011 Expression of sperm adhesion molecule 1 (SPAM1) in cow and sow oviduct. Reproduction in Domestic Animals 46 79. (doi:10.1111/j.1439-0531. 2011.01828.x)

Apichela SA, Valz-Gianinet JN, Schuster S, Jiménez-Díaz MA, Roldán-Olarte EM \& Miceli DC 2010 Lectin binding patterns and carbohydrate mediation of sperm binding to llama oviductal cells in vitro. Animal Reproduction Science 118 344-353. (doi:10.1016/ j.anireprosci.2009.07.008)

Austin CR 1951 Observations on the penetration of the sperm in the mammalian egg. Australian Journal of Scientific Research. Series B: Biological Sciences 4 581-596.

Avilés M, Jaber L, Castells MT, Kan FK \& Ballesta J 1996 Modifications of the lectin binding pattern in the rat zona pellucida after in vivo fertilization. Molecular Reproduction and Development 44 370-381. (doi:10.1002/ (SICl) 1098-2795(199607)44:3 <370::AID-MRD11 > 3.0.CO;2-4)

Aviles M, Jaber L, Castells MT, Ballesta J \& Kan FW 1997 Modifications of carbohydrate residues and ZP2 and ZP3 glycoproteins in the mouse zona pellucida after fertilization. Biology of Reproduction 57 1155-1163. (doi:10.1095/biolreprod57.5.1155)

Avilés M, Gutiérrez-Adán A \& Coy P 2010 Oviductal secretions: will they be key factors for the future ARTs? Molecular Human Reproduction 16 896-906. (doi:10.1093/molehr/gaq056)

Bahat A \& Eisenbach M 2010 Human sperm thermotaxis is mediated by phospholipase $\mathrm{C}$ and inositol trisphosphate receptor $\mathrm{Ca}^{2+}$ channel. Biology of Reproduction 82 606-616. (doi:10.1095/biolreprod.109.080127)

Baillie H, Pacey A, Warren M, Scudamore I \& Barratt C 1997 Greater numbers of human spermatozoa associate with endosalpingeal cells derived from the isthmus compared with those from the ampulla. Human Reproduction 12 1985-1992. (doi:10.1093/humrep/12.9.1985)

Bian F, Mao G, Guo M, Wang J, Li J, Han Y, Chen X, Zhang M \& Xia G 2012 Gradients of natriuretic peptide precursor A (NPPA) in oviduct and of natriuretic peptide receptor 1 (NPR1) in spermatozoon are involved in mouse sperm chemotaxis and fertilization. Journal of Cellular Physiology 227 2230-2239. (doi:10.1002/jcp.22962)

Brenker C, Goodwin N, Weyand I, Kashikar ND, Naruse M, Krähling M, Müller A, Kaupp UB \& Strünker T 2012 The CatSper channel: a polymodal chemosensor in human sperm. EMBO Journal 31 1654-1665. (doi:10.1038/emboj.2012.30)

Buck J \& Levin LR 2011 Physiological sensing of carbon dioxide/ bicarbonate/pH via cyclic nucleotide signaling. Sensors 11 2112-2128. (doi:10.3390/s110202112)

Bureau M, Bailey JL \& Sirard MA 2002 Binding regulation of porcine spermatozoa to oviductal vesicles in vitro. Journal of Andrology 23 188-193.

Burkitt M, Walker D, Romano DM \& Fazeli A 2012 Using computational modeling to investigate sperm navigation and behavior in the female reproductive tract. Theriogenology 77 703-716. (doi:10.1016/j.theriogenology.2011.11.011)

Calvete JJ, Carrera E, Sanz L \& Töpfer-Petersen E 1996 Boar spermadhesins AQN-1 and AQN-3: oligosaccharide and zona pellucida binding characteristics. Biological Chemistry 377 521-527. (doi:10.1515/ bchm3.1996.377.7-8.521)

Campos I, Coy P, Romar R, Ruiz S \& Gadea J 2001 Effects of maturational stage, cumulus cells and coincubation of mature and immature cumulus-oocyte complexes on in vitro penetrability of porcine oocytes. Theriogenology 55 1489-1500. (doi:10.1016/S0093-691X(01)00496-4)

Carrasco LC, Coy P, Aviles M, Gadea J \& Romar R 2008a Glycosidase determination in bovine oviducal fluid at the follicular and luteal phases of the oestrous cycle. Reproduction, Fertility, and Development 20 808-817. (doi:10.1071/RD08113)

Carrasco LC, Romar R, Aviles M, Gadea J \& Coy P 2008b Determination of glycosidase activity in porcine oviductal fluid at the different phases of the estrous cycle. Reproduction 136 833-842. (doi:10.1530/REP-08-0221)

Chang MC 1951 Fertilizing capacity of spermatozoa deposited into the fallopian tubes. Nature 168 697-698. (doi:10.1038/168697b0)

Chang MC 1959 Fertilization of rabbit ova in vitro. Nature 184 (Suppl 7) 466-467. (doi:10.1038/184466a0)

Chang MC 1966 Transport of eggs from the fallopian tube to the uterus as a function of oestrogen. Nature 212 1048-1049. (doi:10.1038/ 2121048b0)
Chang H \& Suarez SS 2010 Rethinking the relationship between hyperactivation and chemotaxis in mammalian sperm. Biology of Reproduction 83 507-513. (doi:10.1095/biolreprod.109.083113)

Chang H \& Suarez SS 2012 Unexpected flagellar movement patterns and epithelial binding behavior of mouse sperm in the oviduct. Biology of Reproduction 140 141-148.

Cho C, Bunch DO, Faure JE, Goulding EH, Eddy EM, Primakoff P \& Myles DG 1998 Fertilization defects in sperm from mice lacking fertilin $\beta$. Science 281 1857-1859. (doi:10.1126/science.281.5384.1857)

Christmas P, Callaway J, Fallon J, Jones J \& Haigler HT 1991 Selective secretion of annexin 1, a protein without a signal sequence, by the human prostate gland. Journal of Biological Chemistry 266 2499-2507.

Coy P \& Avilés M 2010 What controls polyspermy in mammals, the oviduct or the oocyte? Biological Reviews of the Cambridge Philosophical Society 85 593-605. (doi:10.1111/j.1469-185X.2009.00117.x)

Coy P, Martinez E, Ruiz S, Vazquez JM, Roca J \& Gadea J 1993 Environment and medium volume influence in vitro fertilisation of pig oocytes. Zygote 1 209-213. (doi:10.1017/S0967199400001489)

Coy P, Canovas S, Mondejar I, Saavedra MD, Romar R, Grullon L, Matas C \& Aviles M 2008 Oviduct-specific glycoprotein and heparin modulate sperm-zona pellucida interaction during fertilization and contribute to the control of polyspermy. PNAS 105 15809-15814. (doi:10.1073/pnas. 0804422105)

Coy P, Lloyd R, Romar R, Satake N, Matas C, Gadea J \& Holt WV 2010 Effects of porcine pre-ovulatory oviductal fluid on boar sperm function. Theriogenology 74 632-642. (doi:10.1016/j.theriogenology.2010.03.005)

Coy P, Jiménez-Movilla M, García-Vázquez FA, Mondéjar I, Grullón L \& Romar R 2012 Oocytes use plasminogen-plasmin system to remove supernumerary spermatozoa. Human Reproduction 27 1985-1993. (doi:10.1093/humrep/des146)

Demott RP \& Suarez SS 1992 Hyperactivated sperm progress in the mouse oviduct. Biology of Reproduction 46 779-785. (doi:10.1095/ biolreprod46.5.779)

DeMott RP, Lefebvre R \& Suarez SS 1995 Carbohydrates mediate the adherence of hamster sperm to oviductal epithelium. Biology of Reproduction 52 1395-1403. (doi:10.1095/biolreprod52.6.1395)

Dixon RE, Hwang SJ, Hennig GW, Ramsey KH, Schripsema JH, Sanders KM \& Ward SM 2009 Chlamydia infection causes loss of pacemaker cells and inhibits oocyte transport in the mouse oviduct. Biology of Reproduction 80 665-673. (doi:10.1095/biolreprod.108.073833)

Dobrinski I, Ignotz GG, Thomas PG \& Ball BA 1996 Role of carbohydrates in the attachment of equine spermatozoa to uterine tubal (oviductal) epithelial cells in vitro. American Journal of Veterinary Research 57 1635-1639.

Dostàlovà Z, Calvete JJ \& Töpfer-Petersen E 1995 Interaction of nonaggregated boar $\mathrm{AWN}-1$ and $\mathrm{AQN}-3$ with phospholipid matrices. A model for coating of spermadhesins to the sperm surface. Biological Chemistry Hoppe-Seyler 376 237-242. (doi:10.1515/bchm3.1995.376.4.237)

Eisenbach M \& Giojalas LC 2006 Sperm guidance in mammals - an unpaved road to the egg. Nature Reviews. Molecular Cell Biology 7 276-285. (doi:10.1038/nrm1893)

Ekhlasi-Hundrieser M, Gohr K, Wagner A, Tsolova M, Petrunkina A \& Töpfer-Petersen E 2005 Spermadhesin AQN1 is a candidate receptor molecule involved in the formation of the oviductal sperm reservoir in the pig. Biology of Reproduction 73 536-545. (doi:10.1095/biolreprod. 105.040824)

El-Mestrah M \& Kan FW 2001 Distribution of lectin-binding glycosidic residues in the hamster follicular oocytes and their modifications in the zona pellucida after ovulation. Molecular Reproduction and Development 60 517-534. (doi:10.1002/mrd.1117)

Fazeli A, Affara N, Hubank M \& Holt W 2004 Sperm-induced modification of the oviductal gene expression profile after natural insemination in mice. Biology of Reproduction 71 60-65. (doi:10.1095/biolreprod.103.026815)

Funahashi H, Ekwall H, Kikuchi K \& Rodriguez-Martinez H 2001 Transmission electron microscopy studies of the zona reaction in pig oocytes fertilized in vivo and in vitro. Reproduction 122 443-452. (doi:10.1530/rep.0.1220443)

Gadella BM 2010 Interaction of sperm with the zona pellucida during fertilization. Reproduction in Domestic Ruminants 7 265-285. (doi:10. 5661/RDR-VII-267)

Gahlay G, Gauthier L, Baibakov B, Epifano O \& Dean J 2010 Gamete recognition in mice depends on the cleavage status of an egg's zona pellucida protein. Science 329 216-219. (doi:10.1126/science.1188178) 
Georgiou AS, Sostaric E, Wong CH, Snijders AP, Wright PC, Moore HD \& Fazeli A 2005 Gametes alter the oviductal secretory proteome. Molecular \& Cellular Proteomics 4 1785-1796. (doi:10.1074/mcp.M500119-MCP200)

Goncalves RF, Staros AL \& Killian GJ 2008 Oviductal fluid proteins associated with the bovine zona pellucida and the effect on in vitrosperm-egg binding, fertilization and embryo development. Reproduction in Domestic Animals 43 720-729. (doi:10.1111/j.1439-0531.2007.00978.x)

Griffiths G, Miller K, Galileo D \& Martin-DeLeon P 2008 Murine SPAM1 is secreted by the estrous uterus and oviduct in a form that can bind to sperm during capacitation: acquisition enhances hyaluronic acidbinding ability and cumulus dispersal efficiency. Reproduction 135 293-301. (doi:10.1530/REP-07-0340)

Gwathmey TM, Ignotz GG \& Suarez SS 2003 PDC-109 (BSP-A1/A2) promotes bull sperm binding to oviductal epithelium in vitro and may be involved in forming the oviductal sperm reservoir. Biology of Reproduction 69 809-815. (doi:10.1095/biolreprod.102.010827)

Hagaman JR, Moyer JS, Bachman ES, Sibony M, Magyar PL, Welch JE, Smithies O, Krege JH \& O'Brien DA 1998 Angiotensin-converting enzyme and male fertility. PNAS 95 2552-2557. (doi:10.1073/pnas.95.5.2552)

Hess KC, Jones BH, Marquez B, Chen Y, Ord TS, Kamenetsky M, Miyamoto C, Zippin JH, Kopf GS, Suarez SS et al. 2005 The "soluble" adenylyl cyclase in sperm mediates multiple signaling events required for fertilization. Developmental Cell 9 249-259. (doi:10.1016/j.devcel.2005.06.007)

Ho K, Wolff CA \& Suarez SS 2009 CatSper-null mutant spermatozoa are unable to ascend beyond the oviductal reservoir. Reproduction, Fertility, and Development 21 345-350. (doi:10.1071/RD08183)

Hung PH \& Suarez SS 2010 Regulation of sperm storage and movement in the ruminant oviduct. Reproduction in Domestic Ruminants 7 255-264. (doi:10.5661/RDR-VII-257)

Hunter RH 1973 Polyspermic fertilization in pigs after tubal deposition of excessive numbers of spermatozoa. Journal of Experimental Zoology $\mathbf{1 8 3}$ 57-63. (doi:10.1002/jez.1401830107)

Hunter RH 1974 Chronological and cytological details of fertilization and early embryonic development in the domestic pig, Sus scrofa. Anatomical Record 178 169-185. (doi:10.1002/ar.1091780203)

Hunter RHF 1989 Ovarian programming of gamete progression and maturation in the female genital tract. Zoological Journal of the Linnean Society 95 117-124. (doi:10.1111/j.1096-3642.1989.tb02304.x)

Hunter RH 2012 Components of oviduct physiology in eutherian mammals. Biological Reviews of the Cambridge Philosophical Society 87 244-255. (doi:10.1111/j.1469-185X.2011.00196.x)

Hunter RH \& Léglise PC 1971 Tubal surgery in the rabbit: fertilization and polyspermy after resection of the isthmus. American Journal of Anatomy 132 45-52. (doi:10.1002/aja.1001320106)

Hunter RHF \& Nichol R 1986 A preovulatory temperature gradient between the isthmus and ampulla of pig oviducts during the phase of sperm storage. Journal of Reproduction and Fertility 77 599-606. (doi:10.1530/ jrf.0.0770599)

Hunter RH, Coy P, Gadea J \& Rath D 2011 Considerations of viscosity in the preliminaries to mammalian fertilisation. Journal of Assisted Reproduction and Genetics 28 191-197. (doi:10.1007/s10815-010-9531-3)

Ignotz G, Lo M, Perez C, Gwathmey T \& Suarez S 2001 Characterization of a fucose-binding protein from bull sperm and seminal plasma that may be responsible for formation of the oviductal sperm reservoir. Biology of Reproduction 64 1806-1811. (doi:10.1095/biolreprod64.6.1806)

Ikawa M, Wada I, Kominami K, Watanabe D, Toshimori K, Nishimune Y \& Okabe M 1997 The putative chaperone calmegin is required for sperm fertility. Nature 387 607-611. (doi:10.1038/42484)

Ikawa M, Tokuhiro K, Yamaguchi R, Benham AM, Tamura T, Wada I, Satouh Y, Inoue N \& Okabe M 2011 Calsperin is a testis-specific chaperone required for sperm fertility. Journal of Biological Chemistry 286 5639-5646. (doi:10.1074/jbc.M110.140152)

Jin J, Jin N, Zheng H, Ro S, Tafolla D, Sanders KM \& Yan W 2007 Catsper3 and Catsper4 are essential for sperm hyperactivated motility and male fertility in the mouse. Biology of Reproduction 77 37-44. (doi:10.1095/ biolreprod.107.060186)

Jin M, Fujiwara E, Kakiuchi Y, Okabe M, Satouh Y, Baba SA, Chiba K \& Hirohashi N 2011 Most fertilizing mouse spermatozoa begin their acrosome reaction before contact with the zona pellucida during in vitro fertilization. PNAS 108 4892-4896. (doi:10.1073/pnas.1018202108)
Kim E, Yamashita M, Kimura M, Honda A, Kashiwabara S \& Baba T 2008 Sperm penetration through cumulus mass and zona pellucida. International Journal of Developmental Biology 52 677-682. (doi:10. 1387/ijdb.072528ek)

Kirichok Y, Navarro B \& Clapham DE 2006 Whole-cell patch-clamp measurements of spermatozoa reveal an alkaline-activated $\mathrm{Ca}^{2+}$ channel. Nature 439 737-740. (doi:10.1038/nature04417)

Kölle S, Dubielzig S, Reese S, Wehrend A, König P \& Kummer W 2009 Ciliary transport, gamete interaction, and effects of the early embryo in the oviduct: ex vivo analyses using a new digital videomicroscopic system in the cow. Biology of Reproduction 81 267-274. (doi:10.1095/ biolreprod.108.073874)

Krapf D, Arcelay E, Wertheimer EV, Sanjay A, Pilder SH, Salicioni AM \& Visconti PE 2010 Inhibition of Ser/Thr phosphatases induces capacitation-associated signaling in the presence of Src kinase inhibitors. Journal of Biological Chemistry 285 7977-7985. (doi:10.1074/jbc. M109.085845)

Kumaresan A, Johannisson A, Humblot P \& Bergqvist AS 2012 Oviductal fluid modulates the dynamics of tyrosine phosphorylation in cryopreserved boar spermatozoa during capacitation. Molecular Reproduction and Development 79 525-540. (doi:10.1002/mrd.22058)

Lapointe J, Roy M, St-Pierre I, Kimmins S, Gauvreau D, MacLaren LA \& Bilodeau JF 2006 Hormonal and spatial regulation of nitric oxide synthases (NOS) (neuronal NOS, inducible NOS, and endothelial NOS) in the oviducts. Endocrinology 147 5600-5610. (doi:10.1210/en.2005-1548)

Lefebvre R \& Suarez SS 1996 Effect of capacitation on bull sperm binding to homologous oviductal epithelium. Biology of Reproduction 54 575-582. (doi:10.1095/biolreprod54.3.575)

Lefebvre R, Chenoweth PJ, Drost M, LeClear CT, MacCubbin M, Dutton JT \& Suarez SS 1995 Characterization of the oviductal sperm reservoir in cattle. Biology of Reproduction 53 1066-1074. (doi:10.1095/biolreprod53.5.1066)

Lishko PV, Botchkina IL \& Kirichok Y 2011 Progesterone activates the principal $\mathrm{Ca}^{2+}$ channel of human sperm. Nature 471 387-391. (doi:10.1038/nature09767)

Marcello MR, Jia W, Leary JA, Moore KL \& Evans JP 2011 Lack of tyrosylprotein sulfotransferase-2 activity results in altered sperm-egg interactions and loss of ADAM3 and ADAM6 in epididymal sperm. Journal of Biological Chemistry 286 13060-13070. (doi:10.1074/jbc. M110.175463)

Miessen K, Sharbati S, Einspanier R \& Schoen J 2011 Modelling the porcine oviduct epithelium: a polarized in vitro system suitable for long-term cultivation. Theriogenology 76 900-910. (doi:10.1016/j.theriogenology. 2011.04.021)

Mondéjar I, Acuña O, Izquierdo-Rico M, Coy P \& Avilés M 2012a The oviduct: functional genomic and proteomic approach. Reproduction in Domestic Animals 47 (Suppl 3) 22-29. (doi:10.1111/j.1439-0531.2012.02027.x)

Mondéjar I, Grullón LA, García-Vázquez FA, Romar R \& Coy P $2012 b$ Fertilization outcome could be regulated by binding of oviductal plasminogen to oocytes and by releasing of plasminogen activators during interplay between gametes. Fertility and Sterility 97 453-461. (doi:10.1016/j.fertnstert.2011.11.032)

Nakanishi T, Ikawa M, Yamada S, Parvinen M, Baba T, Nishimune Y \& Okabe M 1999 Real-time observation of acrosomal dispersal from mouse sperm using GFP as a marker protein. FEBS Letters 449 277-283. (doi:10.1016/S0014-5793(99)00433-0)

Nishimura H, Kim E, Nakanishi T \& Baba T 2004 Possible function of the ADAM1a/ADAM2 fertilin complex in the appearance of ADAM3 on the sperm surface. Journal of Biological Chemistry 279 34957-34962. (doi:10.1074/jbc.M314249200)

Nolan MA, Babcock DF, Wennemuth G, Brown W, Burton KA \& McKnight GS 2004 Sperm-specific protein kinase A catalytic subunit Calpha2 orchestrates cAMP signaling for male fertility. PNAS 101 13483-13488. (doi:10.1073/pnas.0405580101)

Orihuela PA, Parada-Bustamante A, Cortés PP, Gatica C \& Croxatto HB 2003 Estrogen receptor, cyclic adenosine monophosphate, and protein kinase $\mathrm{A}$ are involved in the nongenomic pathway by which estradiol accelerates oviductal oocyte transport in cyclic rats. Biology of Reproduction 68 1225-1231. (doi:10.1095/biolreprod.102.011395)

Pacey AA, Davies N, Warren MA, Barratt CL \& Cooke ID 1995 Hyperactivation may assist human spermatozoa to detach from intimate association with the endosalpinx. Human Reproduction 10 2603-2609. 
Perez Martinez S, Viggiano M, Franchi A, Herrero M, Ortiz M, Gimeno M \& Villalón M 2000 Effect of nitric oxide synthase inhibitors on ovum transport and oviductal smooth muscle activity in the rat oviduct. Journal of Reproduction and Fertility 118 111-117. (doi:10.1530/reprod/118.1.111)

Publicover S, Harper CV \& Barratt C $2007\left[\mathrm{Ca}^{2+}\right]_{i}$ signalling in spermmaking the most of what you've got. Nature Cell Biology 9 235-242. (doi:10.1038/ncb0307-235)

Publicover SJ, Giojalas LC, Teves ME, de Oliveira GS, Garcia AA, Barratt CL \& Harper CV $2008 \mathrm{Ca}^{2+}$ signalling in the control of motility and guidance in mammalian sperm. Frontiers in Bioscience 13 5623-5637. (doi:10.2741/3105)

Qi H, Moran MM, Navarro B, Chong JA, Krapivinsky G, Krapivinsky L, Kirichok Y, Ramsey IS, Quill TA \& Clapham DE 2007 All four CatSper ion channel proteins are required for male fertility and sperm cell hyperactivated motility. PNAS 104 1219-1223. (doi:10.1073/pnas. 0610286104)

Quill TA, Sugden SA, Rossi KL, Doolittle LK, Hammer RE \& Garbers DL 2003 Hyperactivated sperm motility driven by CatSper2 is required for fertilization. PNAS 100 14869-14874. (doi:10.1073/pnas.2136654100)

Ren D, Navarro B, Perez G, Jackson AC, Hsu S, Shi Q, Tilly JL \& Clapham DE 2001 A sperm ion channel required for sperm motility and male fertility. Nature 413 603-609. (doi:10.1038/35098027)

Rodriguez-Martinez H 2007 Role of the oviduct in sperm capacitation. Theriogenology 68 (Suppl 1) S138-S146. (doi:10.1016/j.theriogenology. 2007.03.018)

Rodriguez-Martinez H, Tienthai P, Suzuki K, Funahashi H, Ekwall H \& Johannisson A 2001 Involvement of oviduct in sperm capacitation and oocyte development in pigs. Reproduction Supplement 58 129-145.

Shamsadin R, Adham IM, Nayernia K, Heinlein UA, Oberwinkler H \& Engel W 1999 Male mice deficient for germ-cell cyritestin are infertile. Biology of Reproduction 61 1445-1451. (doi:10.1095/biol reprod61.6.1445)

Smith TT \& Yanagimachi R 1991 Attachment and release of spermatozoa from the caudal isthmus of the hamster oviduct. Journal of Reproduction and Fertility 91 567-573. (doi:10.1530/jrf.0.0910567)

Song C, Gao B, Wu H, Wang X, Chen G \& Mao J 2010 Spatial and temporal expression of spermadhesin genes in reproductive tracts of male and female pigs and ejaculated sperm. Theriogenology 73 551-559. (doi:10.1016/j.theriogenology.2009.09.030)

Sostaric E, Dieleman SJ, van de Lest $\mathrm{CH}$, Colenbrander B, Vos PL, Garcia-Gil N \& Gadella BM 2008 Sperm binding properties and secretory activity of the bovine oviduct immediately before and after ovulation. Molecular Reproduction and Development 75 60-74. (doi:10.1002/mrd.20766)

Stauss CR, Votta TJ \& Suarez SS 1995 Sperm motility hyperactivation facilitates penetration of the hamster zona pellucida. Biology of Reproduction 53 1280-1285. (doi:10.1095/biolreprod53.6.1280)

Steptoe PC \& Edwards RG 1978 Birth after the reimplantation of a human embryo. Lancet 2 366. (doi:10.1016/S0140-6736(78)92957-4)

Strünker T, Goodwin N, Brenker C, Kashikar ND, Weyand I, Seifert R \& Kaupp UB 2011 The CatSper channel mediates progesterone-induced $\mathrm{Ca}^{2+}$ influx in human sperm. Nature 471 382-386. (doi:10.1038/ nature09769)

Suarez S 2002 Formation of a reservoir of sperm in the oviduct. Reproduction in Domestic Animals 37 140-143. (doi:10.1046/j.14390531.2002.00346.x)

Suarez SS 2008a Control of hyperactivation in sperm. Human Reproduction Update 14 647-657. (doi:10.1093/humupd/dmn029)

Suarez SS 2008b Regulation of sperm storage and movement in the mammalian oviduct. International Journal of Developmental Biology $\mathbf{5 2}$ 455-462. (doi:10.1387/ijdb.072527ss)

Suarez SS \& Dai X 1992 Hyperactivation enhances mouse sperm capacity for penetrating viscoelastic media. Biology of Reproduction 46 686-691. (doi:10.1095/biolreprod46.4.686)

Suarez SS \& Ho HC 2003 Hyperactivation of mammalian sperm. Cellular and Molecular Biology 49 351-356.

Suarez S, Redfern K, Raynor P, Martin F \& Phillips DM 1991 Attachment of boar sperm to mucosal explants of oviduct in vitro: possible role in formation of a sperm reservoir. Biology of Reproduction 44 998-1004. (doi:10.1095/biolreprod44.6.998)
Sun TT, Chung CM \& Chan HC 2011 Acrosome reaction in the cumulus oophorus revisited: involvement of a novel sperm-released factor NYDSP8. Protein Cell 2 92-98. (doi:10.1007/s13238-011-1022-5)

Talbot P, Shur BD \& Myles DG 2003 Cell adhesion and fertilization: steps in oocyte transport, sperm-zona pellucida interactions, and sperm-egg fusion. Biology of Reproduction 68 1-9. (doi:10.1095/biolreprod.102. 007856)

Talevi R \& Gualtieri R 2010 Molecules involved in sperm-oviduct adhesion and release. Theriogenology 73 796-801. (doi:10.1016/j.theriogeno logy.2009.07.005)

Teilmann SC, Clement CA, Thorup J, Byskov AG \& Christensen ST 2006 Expression and localization of the progesterone receptor in mouse and human reproductive organs. Journal of Endocrinology 191 525-535. (doi:10.1677/joe.1.06565)

Tokuhiro K, Ikawa M, Benham AM \& Okabe M 2012 Protein disulfide isomerase homolog PDILT is required for quality control of sperm membrane protein ADAM3 and male fertility [corrected]. PNAS 109 3850-3855. (doi:10.1073/pnas.1117963109)

Van Soom A, Tanghe S, De Pauw I, Maes D \& de Kruif A 2002 Function of the cumulus oophorus before and during mammalian fertilization. Reproduction in Domestic Animals 37 144-151. (doi:10.1046/j.14390531.2002.00345.x)

Vijayaraghavan S, Goueli SA, Davey MP \& Carr DW 1997 Protein kinase A-anchoring inhibitor peptides arrest mammalian sperm motility. Journal of Biological Chemistry 272 4747-4752. (doi:10.1074/jbc.272.8.4747)

Visconti PE, Moore GD, Bailey JL, Leclerc P, Connors SA, Pan D, Olds-Clarke P \& Kopf GS 1995 Capacitation of mouse spermatozoa. II. Protein tyrosine phosphorylation and capacitation are regulated by a cAMP-dependent pathway. Development 121 1139-1150.

Visconti PE, Krapf D, de la Vega-Beltrán JL, Acevedo JJ \& Darszon A 2011 Ion channels, phosphorylation and mammalian sperm capacitation. Asian Journal of Andrology 13 395-405. (doi:10.1038/aja.2010.69)

Xie F, Garcia MA, Carlson AE, Schuh SM, Babcock DF, Jaiswal BS, Gossen JA, Esposito G, van Duin M \& Conti M 2006 Soluble adenylyl cyclase (sAC) is indispensable for sperm function and fertilization. Developmental Biology 296 353-362. (doi:10.1016/j.ydbio.2006.05.038)

Yanagimachi R 1970 The movement of golden hamster spermatozoa before and after capacitation. Journal of Reproduction and Fertility 23 193-196. (doi:10.1530/jrf.0.0230193)

Yanagimachi R 1994 Mammalian fertilization. In The Physiology of Reproduction, pp 189-317. Eds Knobil E \& Neil JD. New York, NY, USA: Raven Press.

Yanagimachi R 2011 Mammalian sperm acrosome reaction: where does it begin before fertilization? Biology of Reproduction 85 4-5. (doi:10.1095/ biolreprod.111.092601)

Yin L, Chung CM, Huo R, Liu H, Zhou C, Xu W, Zhu H, Zhang J, Shi Q, Wong HY et al. 2009 A sperm GPI-anchored protein elicits spermcumulus cross-talk leading to the acrosome reaction. Cellular and Molecular Life Sciences 66 900-908. (doi:10.1007/s00018-009-8482-2)

Yonezawa N, Amari S, Takahashi K, Ikeda K, Imai F, Kanai S, Kikuchi K \& Nakano M 2005 Participation of the nonreducing terminal $\beta$-galactosyl residues of the neutral $\mathrm{N}$-linked carbohydrate chains of porcine zona pellucida glycoproteins in sperm-egg binding. Molecular Reproduction and Development 70 222-227. (doi:10.1002/mrd.20195)

Yoshida M \& Yoshida K 2011 Sperm chemotaxis and regulation of flagellar movement by $\mathrm{Ca}^{2+}$. Molecular Human Reproduction 17 457-465. (doi:10.1093/molehr/gar041)

Zhuo L, Yoneda $M$, Zhao $M$, Yingsung $W$, Yoshida N, Kitagawa $Y$, Kawamura K, Suzuki T \& Kimata K 2001 Defect in SHAP-hyaluronan complex causes severe female infertility. A study by inactivation of the bikunin gene in mice. Journal of Biological Chemistry 276 7693-7696. (doi:10.1074/jbc.C000899200)

Zumoffen CM, Caille AM, Munuce MJ, Cabada MO \& Ghersevich SA 2010 Proteins from human oviductal tissue-conditioned medium modulate sperm capacitation. Human Reproduction 25 1504-1512. (doi:10.1093/ humrep/deq063)

Received 19 July 2012

First decision 13 September 2012

Accepted 28 September 2012 